\title{
Children's Rights: Syrian Refugee Camps ..Childhood Underfire?
}

\author{
HRH PR. Fahdah Fahad Khalid Nasser Abdullaziz Alsaud ${ }^{1}$ \\ ${ }^{1}$ Middlesex University, London, UK \\ Correspondence: HRH PR. Fahdah Fahad Khalid Nasser Abdullaziz Alsaud, Middlesex University, London, UK. \\ E-mail: mkt-mro@hotmail.com
}

Received: June 4, 2015 Accepted: June 11, 2015 Online Published: August 28, 2015

doi:10.5539/jpl.v8n3p228

URL: http://dx.doi.org/10.5539/jpl.v8n3p228

\begin{abstract}
This dissertation focuses on the displacement taking place in Syria. The conflict resulted from the spillover from the Arab Spring uprising but many different exploited groups have been under fire. Perhaps most important of those are children, who find themselves in the crosshairs. Children have been affected in dramatic waysand have suffered mental and physical injuries leading to displacement. This study questions individual perceptions of the conflict, and the role of international organizations in providing critical support to the problems faced by children in the syria. This study utilizes both primary and secondary source materials in order to come to an answer to these critical research questions and will also give recommendations and insights of further possible solutions to the rights of these helpless children in the mist of this crisis.
\end{abstract}

Keywords: children rights, childhood, Syrian refugee, camps

\section{Introduction:}

Syria has been facing an ongoing and severe crisis for more than three years. Since the beginning of the crisis, the "forgotten" victims have been children, who have faced hunger, harassment, death, and trauma. These children have been deprived of the benefit of humanitarian aid, living in misery.To this end, the degree of their suffering has been insurmountable (UNICEF, 2014). The effect of three years of terror is even more important for children, who, because of the short nature of their lives, feel the brunt of three years more than an adult might. These years are transformative for children, who are often moving from one phase in life to the other. These three years could have proven to be a lifetime achievement for high school students, thoroughly preparing themselves to contribute constructively to society. Children in Syria are deprived of these feelings and achievements to say the least. The past three years of the crisis have been the longest years of their lives. The state of loss, despair, depression, suffering and pain has been immense, and living in this state is the most damaging conflict for the children in the recent history of the region.

Further exacerbating the negative consequences of the excruciating conflict is the fact that more than 5.5 million Syrian children imagine their future besieged by war, and this cannot be ignored (Council report, 2014). Much of the loss is unrecoverable; children have lost their limbs and lives, their teachers, their friends, their family and, ultimately, their stability. Instead of playing and learning, these children are forced to work, being recruited as soldiers and subjected to enforced idleness. According to United Nations (UN), the estimated number of children being killed in Syria is at least 10,000. The reality could actually be much larger than this number. These killings are a result of conflicts and incorporate states of deaths, injuries, and disabilities (UNICEF, 2014, p. 5).

The overall system of Syria has been torn apart because of the accelerating crisis. It has been estimated that the more than three million buildings have been destroyed, along with the critical infrastructure and the social system. More than six million people have been displaced inside the country that is more than a third of the Syrian children deprived of living in their own homes and communities (Save the Children, 2014, p.77). The pre-war lives have become a distant memory for the young children, and these experiences have become so normal for these children that, despite the suffering, they show immense courage and compassion. In short, young people have learned the skill of resilience in perhaps the worst way imagineable.

\section{Ongoing Conflict in Syria}

This chapter of the study provides previously-conducted similar studies and researches of various researchers from different public, as well as, private libraries including academic journals. The purpose of this chapter is to enhance the understanding of the researcher, as well as, the potential readers of the study. 
Nearly 42 months have passed since the conflict in Syria began, which has resulted into increased civilian causalities, internal and external human displacement, and destruction of infrastructure, homes, and livelihood of the people living there. It was a reaction to the Arab Spring and a series of anti-government protests in different regions of the Arab World falling under the Tunisian regime (Manfreda, 2013). It was the anger and frustration among the common men that led to the uprising conflict, as they were a victim of unemployment, decades of dictatorship, corruption, and the state violence under the most repressive regimes of Middle East (Manfreda, 2013).

Syria is a society with mixed religion, and there is an increase in the sectarian nature of violence in several parts of the country, which have contributed to an increased tension between Sunni-Shiite factions in the Middle East (Pillay, 2014). The neighbouring countries, such as Iraq, Lebanon, Jordan, and Turkey have also been affected by the chaos in Syria, creating a disaster region-wide. Global powers, such as European Union, US ,and Russia, in an effort to resolve the conflict, have played a very important role in the civil war of Syria (Current crisis in Syria, 2014, p. 7).

This disastrous conflict in Syria over the period of more than three years has resulted in a death toll of more than 100,000 men, women, and children, and millions more have been displaced (Syria - Complex Emergency, 2012, p.4). The current condition of the country is unsafe for all those living there - especially the children. Children of all ages who have survived during the war and have face high risk of exploitation, violence, negligence, and abuse are the ones paying for the ongoing conflict.

With each day passing in Syria, the humanitarian situation is worsening, as the brutality and scale of the conflict have intensified and worsened the current situation. Children are the ones who are affected the most, as there is a worsening situation of the civil war. Within the borders of Syria, more than half of the 6.5 million people are the children who are displaced, and around 4.3 million children are in desperate need of basic necessities, including food, shelter, clothing, medication, and psychosocial support (Emergency Alert, 2014, p. 3).

\subsection{Impact of Crisis on Children}

The three-year long year crisis has badly affected the lives of children and has ruined their futures. The civil war crisis has not only affected the children living in the region, but also affected those in the refugee camps. The productive health and growth of the children is weakened by malnutrition and illness as a result of which, these children are also facing traumatic problems. These children are unable to get adequate education, proper health facilities and even basic needs through which they can improve their psychological health and can explore more developmental opportunities. The Future of Syria - Refugee Children in Crisis," details the fracturing of families, with more than 70,000 Syrian refugee families living without fathers, and over 3,700 refugee children unaccompanied or separated from both parents (UNHRC Reports, 2013). The impact of crisis on these children is extremely alarming.

UNICEF reported that Syria is one of the most dangerous places in the world to be a child. They report that 6.5 million Syrian children have been directly affected by brutal conflict that has lasted for longer than three years. One million of these children are living as refugees in neighbouring countries and 2.8 million children are no longer attending school. This is not a political stake, this is these children's future. The war in their home country is brutal, it has taken away their right to safety and to grow up safely in the country and culture for which they know.

Children are vulnerable. Refugee children are even far more vulnerable than the normal child. These children are susceptible to violence, malnutrition, disease, physical injury, and exploitation to name a few. Children are dependent. They need the support of adults, not only for physical survival, particularly in the early years of childhood, but also for their psychological and social well-being (Ogata, n.p). Children are at their developmental stage. They grow in developmental sequences, like a tower of bricks, each layer depending on the one below it. Serious delays interrupting these sequences can severely disrupt development (Ogata, n.p). Delays much like the conflict in Syria. These children are in serious danger in their own homes, and are being forced to seek refuge elsewhere.

The CRC rights focus on the best interest in a child's life, but there are three rights which are so fundamental they are assumed instead of dictated. These include: the "best interests" rule, non-discrimination, and the right to participate. These three rights are so important and so interrelated that it is helpful to think of them as a "triangle of rights". The three rights of the triangle reinforce each other to reach the objective: "the survival and development" of children (Ogata, n.p). Clearly the issues in Syria are directly affecting the ability of children to develop and even survive. This is no place for children to be. 
It is important to understand that culture is a part of the child and must be considered a human right. A child's culture provides them with their continuity and identity. The children learn their traditions and values through culture, they also find their fit in their community, society, and families. There is accumulated knowledge in each society, which is shown through their ways of explaining and interpreting the world in which they live and through their religious and social beliefs. Cutlure also dictates the societal values which controls and rules while ensuring such values are upheld. Society has a direct role in how children are raised. A vital factor that these children refugees are missing is the culture for which they are accustom. Changing culture requires society to incorporate change gradually to ensure these children evolve consistent and coherent manner.

A refugee movement can disrupt nearly every aspect of a culture. The social upheaval caused by the involuntary movement of individuals, families and communities, can dramatically affect the coherence of their culture. Normal social rules, values and controls begin to break down when the social group which provides the framework for their application disintegrates (Ogata, n.p). Every aspect of normality that children understand is stripped away and they are afforded a new way of life. Often new languages, religious beliefs, cultures, a new way of life. This is extremely detrimental on a developing child, especially if the refugee camps do not provide them safety as the children believed they would.

\subsection{Rights of Children in Refugee Camp}

The three-year long crisis has made over 1.2 million children refugees! As Syrian children need a safe and secure place where they can enjoy their rights with prestige (War Child Holland, 2013, pp 12-13). In refugee camps, Syrian children are provided with such activities through which normality among them can be restored (for example, basic food, education, playing and psychosocial activities). The international communities, which are funding and supporting the refugee camps, are making untiring efforts for creating recreational facilities for Syrian children. It has been observed that education plays an important role in the psychological development and well-being of children; therefore, these communities are providing sense of normalcy and safety.

Refugee camps are not intended to serve children. UNHCR describes these camps as "a deliberate and coherent package and administrative measures whereby a group of refugees is enabled to settle on land, usually in an uninhabited or sparsely-populated area, with a view to creating new self-supporting rural communities that ultimately will form part of the economic and social system of the area" (Harrell-Bond, 2000: p.3). This is merely a band aid to cover the real issues going on. It does not facilitate the best needs of the child, which dictates protection for these children.

There is a significant question as to whether refugee camps consider the best interest of the children. Relief programmes by-pass local institutions, they set up expensive parallel systems to deliver services targeted to refugees, then normally destroy them when they go away (Harrell-Bond, 2000: p.3). This challenges the rights of the children as well. The local governmental laws which dictate working age and other protective legislation can be bypassed. This takes the child's rights away and implements what is best for the majority. Refugee camps have too many children and not enough resources to efficiently help them.

Refugee camps implement child protection strategies. These are pretty practical strategies like traveling in groups. They are also taught to avoid or run away from confrontation. Other strategies mentioned were: staying indoors at night and "keeping busy" to remain out of harm's way. Trying harder to blend in with the local population (through dress and language) was a potential strategy mentioned in a few PAs. (UNHCR, 2007: p.2) Education was viewed as a long-term and short-term protection strategy. They knew that education was the best method for future jobs and the ability to support themselves.

The Syrian children refugees are facing the same battles that Southern Africa has as well. The includes: widespread sexual and gender-based violence, inadequate information about HIV/AIDS, lack of knowledge of and respect for children's rights, weak social service delivery and the special vulnerability of orphans. Ethnic tensions that originated in countries or regions of origin appear to be exacerbated when these groups share the same refugee camp, while competition for scarce resources within most host countries is aggravated by the presence of refugee communities (UNHCR, 2007: p.22).

\section{Right of the Children in the International World}

The children of the international world are entitled to the same rights that children in America are afforded. There are many humanitarian organizations that are in place worldwide to protect the children from cultural rituals, violence, exploitation, war. One of most important rights for any child is safety. Organizations such as UNICEF provide program responses such as WASH, which is a clean water program. They also provide education and child protection from the situation in their home country. They also supply health and nutrition 
training and resources to ensure the child is getting the proper nourishments. Also supplies and logistics. These are just a few rights that human rights organizations mandate for children. Children have the right to live in a world free of violence and danger.

\subsection{The Benefits of Child Participation in Humanitarian Programming}

Children in humanitarian programs are to receive the necessary shelter, food, clothing, and education amongst other things. These are the generic guiding principles of internal displacement which is intended to benefit children in their local humanitarian program. Internal displacement typically implicates the following human rights, among others: the right to food; the right to shelter and adequate living conditions; the right to health care; the right to life and personal integrity; the right to work and to an adequate wage; freedom of residence and movement; the right to family unity; the right to education; the right to legal personality; and freedom of thought, association, expression and assembly. (Monitoring, p. 181). This is the basics of benefits for associating in the present humanitarian programs.

Humanitarian programs vary from location to location. Turkey has set up an ideal refugee camp for the Syrian individuals who needed to relocate. "Many of the world's displaced live in conditions striking for their wretchedness, but what is startling about Kilis is how little it resembles the refugee camp of our imagination. It is orderly, incongruously so. Residents scan a card with their fingerprints for entry, before they pass through metal detectors and run whatever items they're carrying through an X-ray machine. Inside, it's stark: 2,053 identical containers spread out in neat rows. No tents. None of the smells - rotting garbage, raw sewage - usually associated with human crush and lack of infrastructure" (McClelland, 2014: n.p). This refugee camp is not like the other. These type of resources are not in every location, however they do provide substantial benefit to the children who take shelter in such refugee camps.

Humanitarian programs also allow children to seek shelter when their homes and families are no longer there to keep the safe. The turmoil in Syria has torn families apart, with over 3,700 children in Jordan and Lebanon living without one or both of their parents, or with no adult caregivers at all. By the end of September 2013, UNHCR had registered 2,440 unaccompanied or separated children in Lebanon and 1,320 in Jordan. In some cases the parents have died, been detained or sent their children into exile alone out of fear for their safety. (The Future, 2014: p,9). These children need a place to go where they can make a new life. It takes them off of the street and gives them direction for their future.

\subsection{Protection for Displaced Children}

Refugee camps are often the option for protecting displaced children. However, there is concern for those who are living in a refugee or an IDP camp. The largest concern is the physical, psychological, and emotional pressures which occur in such 'protective' camps. 'It may be difficult to link one particular pressure with the violation of a specific human right; however, camp life can result in a harsh environment which may pose challenges to the respect of individual and group rights" (Monitoring, p. 171). Understanding the reality of such camps is important to understanding the basic of human rights being provided. The very form of saving these children from the violence on their home soil can be creating a whole new set of issues.

There is a limitation to monitory and protecting these refugees based on the overcrowding and under-manning of these camps. Many of the refugees are forced to leave their lives as they know it for the duration of their stay. "It is virtually impossible for people to make plans for the future when they have no idea how long they will remain where they are. Refugees and IDPs are rarely able to make progress economically, and may struggle to maintain a subsistence living" (Monitoring, p. 172). This is a higher concern for children as many are forced to work to support themselves and their family during this time of relocation. The camps are typically overcrowded. This can create an environment that is exacerbated by frustration and tension.

Accommodations such as basic sanitation and hygiene are extremely hard to monitor with such a large strain of people utilizing the camp. This creates a significant strain of contagious illness which can lead to disability or death. "Children often have only limited access to education. Adolescents, in particular, frequently find that there are no secondary, vocational or other further education opportunities suited to them. Massive unemployment is common among adults who are obliged to depend entirely on humanitarian assistance” (Monitoring, p. 172). This offers minimal protection for these children, at best.

The safety of the children have been compromised based on West refused to intervene and has accepted so few refugees. However, there is still a significant question regarding the legitimacy of the humanitarian organizations in place. David Rieff raises the questions of such organizations losing vision on their primary purpose. Rieff believes the core assumptions of humanitarianism - sympathy for victims and antipathy for oppressors and 
exploiters - represent the best side of the human spirit (Rieff, 2002). The situation in Syria however raises the doubt that this is what is happening. Displaced, under cared for, and safety is subpar at best, leads to the question, who are these groups really aiding? If these children are not being protected, they are essentially failing to do their part.

Humanitarian agencies have rushed to the aid of these children, however their situation does not appear to be much better than their prior situation. Rieff is critical of many aspects of the humanitarian enterprise per se. He denounces the unseemly rush to deploy, the cut-throat competition for funding, and the advertising campaigns insisting that generous donations will make the lives of victims whole again. Agency advocacy materials often attempt to transport the public to a "humanitarian tragedy-land" - a world of "wicked warlords, innocent victims and noble aid workers" (Rieff, 2002). According to Rieff, it is important to question the potential that these organization which are in place to offer international relief in the time of need are not employing the resources as they claim. This would require additional research to validate if this is truly the case and to what extent. However, it clear to see the lack of cooperation from many location and it detrimental effect on the children.

\subsection{Affects and Global Impact}

War has its global impact in many ways. Depending on the location it can have an economic influence depending on their focus of production. However the biggest impact is the displaced citizens who are forced to flee the country for safety. It puts a significant strain on resources and the ability to adequately provide for these individuals. Child labor has reached critical levels. UNICEF estimates that one in ten Syrian refugee children in the region is engaged in child labor. UNHCR and partners said it is one of the most widespread and complex of all child protection problems. (The Future, 2014: p,9). Global impact ultimately affects every country and exploitation effects everyone.

Human trafficking and child labor are just two of the growing issues worldwide. With such access to displace children, there is a concern for these issues to spike at an all-time high.

Child labor is illegal in both Jordan and Lebanon, and running afoul of the law was a major concern raised by working boys during focus group discussions in both countries. During individual interviews, two boys in Jordan reported that they had previously been arrested and held for over five hours(The Future, 2014: p,9). Children are forced to do whatever they need to do in order to provide for themselves and their families. The protection of children is a global responsibility, therefore it has a significant global impact when it is not protected accordingly.

There is also the long-term damage that these children face. Both physical and emotional.

The conflict in Syria has taken an acute physical and psychological toll on refugee children. They have witnessed unspeakable horror, which they struggle to forget. Bombs and missiles have destroyed their homes, communities and schools. Friends and family members were killed, sometimes before their own eyes (The Future, 2014: p,9). The conflict in Syria has a significant impact on the humanitarian considerations. Humanitarian and human rights are a global initiative, failure to implement such factors could raise even more conflict than is already present.

Syrian militant have also been confirmed for deliberately targeting civilians and humanitarian workers. According to the International Criminal Court (ICC) this constitutes as crimes against humanity and war crimes. This becomes a global issue. One of the most shocking reports, produced by the Oxford Research Group, showed that by the end of August 2013,10\% of all recorded civilian deaths in the conflict were of children under $18(11,420$ out of an overall total of 113,735). Of these, seven out of ten were caused by explosive weapons and one in four by small arms fire "including children summarily executed and targeted by snipers." Of the 764 children recorded as summarily executed, "112 were reported to have been tortured, including some of infant age"(Aaronson, 2014). Terrorism is affects everyone globally.

\subsection{The Role of Child in Making a Change}

The focus of the Syrian uprising is primarily the children. These children are the victims in this war, and are given very little options for survival. "Examination of the short-term or immediate effects of the lack of education on refugee children is also alarming. During the crisis, children are the most vulnerable. Many witness horrifying scenes and are subjected to grave violence. Schooling is one way to normalize the life of a child who has been subjected to such trauma. It allows them to feel secure and regain stability and a sense of normalcy. Schools are also one way in which Syria's children can begin the healing process after the physiological damage 
they had endured" (Charles and Denman, 2013). These children are forced to relocate and start from scratch, often void of their families and friends they were accustom to.

\section{World Impact and the Impact of the Syrian Crisis on the Children in the Future}

There has been a substantial world impact and the impact of the Syrian crisis on the children in the future. Syria is considered to be the most dangerous place in the world to be a child. There are many humanitarian organizations that have aided in what is considered the largest operation in history. There are many organizations such as UNICEF that has been on the ground since this conflict occurred. They are working with other partners to immunize an estimated 20 million children in the region following a polio outbreak. They also provided

10 million people with safe drinking water; and education, physical protection, psychological support and winter clothes to refugee children. This is important to ensure that these refugees are not spreading diseases and other ailments in their location of refuge.

\subsection{Palestine's Children and Their Future}

A similar war occurred in Palestine, and these children had to seek refuge elsewhere. However, these children were misdirected and led them to terroristic activities and other unfavorable situations. The challenge between the locals and refugees created competition for work, and as long as the policy is in place to settle these refugees into the local communities, the competition will continue. A larger involvement on a municipality level could address this problem by introducing labor-intensive projects to create jobs for both locals and refugees. This method was introduced in the Palestinian territories after the second intifada and the implementation of the Israeli closure policies. (Christophersen, 2014). The lack of resources forced the Palestinian children into terrorism and other unfavorable options as a source of survival.

The Palestinian Syrians have faced a change in lifestyle and their ability to be mobile. This have forced them to reposition their identity, and inevitably redistributed the power and behavior. This affects men, women and children in diverse ways. Gendered life is controlled by certain habitual presumptions, which often manifests in violent behaviors that are generated in society. Such habitual choices are not a process of deliberate and open choice. These socially learnt dispositions are generated through normative performativity and sustain people in reproducing the structural hegemonies and hierarchies(Charles and Denman, 2013). This passes on the tradition of war to the children.

\subsection{World Wide Issues Associated with the Syrian People}

There are worldwide issues associated with the Syrian people. The economic and political considerations are significant. It greatly uproots society by implementing such a strain on resources. Offering refuges a safe haven is also a worldwide issue. Refugees are extremely vulnerable to exploitation and abuse. War cannot go unnoticed or unaddressed. The children are the real victims in the Syrian outbreak. Relocating these innocent parties out of harms war is a responsibility of everyone. This is also costly in both money and resources.

\section{Conclusion}

The ongoing crisis in Syria is just one of the many global issues that are directly affecting the innocent, the children. The likelihood of their survival is directly dependent upon the resources provided to these children. There are many different problems being faced by Syrian children due to the ongoing conflict. The lack of safety in their own nation is the most significant. They have to seek shelter in neighbouring countries leaving their families, their cultures, and what they know behind. They are extremely vulnerable and often are victims to their environment. Children of refugees do not have social lives, they are outcast from their new communities and when families are present these children need to work to support their family.

The expected results after the successful execution of the research, are believed to reveal that the current situation of children in Syria can make better through different interventions. The basic humanitarian needs will be available to these children, if international communities take necessary steps. Moreover, it is expected that the childhood of Syrian children in refugee camps will also be protected and secure. This is not only a responsibility of the surrounding locations, but it is a worldwide initiative.

The Syrian refugee children are suffering in other ways outside of the war zone from a lack of education, food, supplies and so on. "Among the solutions suggested most frequently were the need for better security, the importance of having access to adults who will listen to and protect them, and the need for better care and protection of unaccompanied and separated children" (UNHCR, 2007: p.3). The safe shelter is a step up from where they came from, however it is far from what they need for adequate survival. 


\section{Limitations}

Whereas alternate war zones where children are at substantial risk, such as Palestine, will be references, the limitations of this study will be on Syria and the refugee locations for the children. This dissertation is based on the best practice for handling displaced children from war zones. This study will have direct interviews with international organizations that protect the aforementioned children. In addition, the resources utilized will be existing research and case studies that show the impact of such crisis and its effect on the true victims, the children.

This literature based nature of this study dictates that it is heavily dependent on existing research and studies that have been successfully concluded on Syrian children and where they find their refuge. It depends on UNICEF and UNHCR to examine the situation through the eyes of the children who are affected from this crisis. The literature may not account for the latest finding and developments associated with the children. The various humanitarian intervention worldwide programs will be analysed for their involvement and success with implementation. Culture plays a vital role in the conflict and needs to be considered in this analysis. Narrowing down the parameters to focus primarily on the Syrian children will provide a basis for which this dissertation will evolve around.

\section{Recommendations}

The worldwide focus is primarily on the refugee children of Syria. There are many issues that these children are facing. Many of these Syrian children have been exploited in some manner by adults. Firth talks about Melody much like the Syrian children has faced exploitation and been failed by the adults in her life. Her parents died in a car crash and she was left with her terminally ill grandmother. Upon convincing her grandmother she needed a break, her friend took Melody to UK for the holiday. She was forced into slavery and trafficking. After years of abuse she fought back and was thrown onto the street. A child with no place to go. The Refugee Council supports vulnerable children like Melody who have been trafficked to the UK through no fault of their own. The Refugee Council can find them a safe place to stay and give them the practical help they need to move on with their lives, even when they've suffered for years as Melody had (Firth, 2014).

Allowing a child to educate themselves in one of the strongest forces that anyone can provide. The old Chinese proverb Give a man a fish and you will feed him for a day. Teach a man to fish and you will feed him for a lifetime, holds vast truth for these children as well. There is no known end to the war in Syria, and inevitably, war on other soil will surface threatening a new batch of children. Providing a safe haven for these children to continue on with their lives is vital. This includes providing the necessities such as food, water, a safe place to seek shelter, and the resources to prepare for their future. The opportunity for exploitation is high; this is why it is so important to teach a child to prepare themselves for whatever their future life throws at them. This is an addition to many refugee camps that currently exist. Resources are scarce and education is often overlooked.

\section{References}

Aaronson, M. (2014). Syria and the Crisis of Humanitarian Intervention. E-International Relations. Retrieved from http://www.e-ir.info/2014/02/11/syria-and-the-crisis-of-humanitarian-intervention/

ACAPS. (2012). Disaster Needs Analysis. Update: Syria. Retrieved from www.acaps.org/disaster-needs-analysis

ACU. (2013). Joint Rapid Assessment of Northern Syria. Interim Report (draft)', pp 18, 31.

Arab Reform Initiative. (2013). Options for future health policies in Syria. Retrieved from http://www.arab-reform.net/sites/default/files/SyriaPaper_HealthPolicies_FuadM.Fuad_Oct13_Final_Layou t_En.pdf

BBC. (2012). Food and hunger amid battle for Aleppo. Retrieved from http://www.bbc.co.uk/news/world-middle-east-19042700

Besheer, M. (2013). UN: More than 1000 Syrian Children are Refugees. Retrieved from $\mathrm{http}: / / \mathrm{www} . v 0 a n e w s . c o m / c o n t e n t /$ united-nations-reports-says-more-than-one-million-syrian-refugees-are-c hildren/1800718.html

Bhalla, R. (2011). Making Sense of the Syrian Crisis. Start for Global Intelligence, 5-9. Retrieved from http://relooney.info/SI_ME-Crisis/Syria_23.pdf

Calculations by Save the Children. (2010). The number of live births expected per day among Syrian refugees is estimated according to standard methodology. pp. 77.

Charles, L., \& Denman, K. (2013). Syrian and Palestinian Syrian Refugees in Lebanon: the Plight of Women and 
Children. Journal of International Women's Studies, 14(5), 96-111. Retrieved from http://vc.bridgew.edu/jiws/vol14/iss5/7Collins, K. M. T

Christophersen, M. (2014). Absence of Syrian Refugee Camps in Lebanon Heats Up Labor Competition and Local Tensions. Global Observatory. Retrieved from http://theglobalobservatory.org/analysis/699-absence-of-syrian-refugee-camps-in-lebanon-heats-up-labor-co mpetition-and-local-tensions-.html

CNN. (2013). Syria's other crisis. $\quad$ Retrieved from http://globalpublicsquare.blogs.cnn.com/2013/09/30/syrias-other-crisis

Collins, K. M. T., Onwuegbuzie, A. J., \& Jiao, Q. G. (2006). Prevalence of mixed methods sampling designs in social science research and beyond. Paper presented at the meeting of the American Educational Research Association, San Francisco.

Cornell University Blog. (2014). Syrian Game Theory. Retrieved from http://blogs.cornell.edu/info2040/2013/10/04/syrian-game-theory/

Creswell, J. W. (2012). Qualitative inquiry and research design: Choosing among five approaches.

Creswell, J. W., \& Clark, V. L. P. (2007). Designing and conducting mixed methods research. Thousand Oaks, CA: Sage publications. Retrieved from http://onlinelibrary.wiley.com/doi/10.1111/j.1753-6405.2007.00097.x/full

Creswell, J. W., \& Creswell, J. W. (2009). Research design: qualitative, quantitative, and mixed methods approaches (3rd ed.). London. Oxford University Press.

Davis, R., \& Woodward, M. (2012). Syrian Refugee Photo Essay. Jadaliyya. Retrieved from http://www.jadaliyya.com/pages/index/6836/syrian-refugee-photo-essay

Doran, M. S. (2002). Somebody else's civil war. Foreign Affairs, 22-42. Retrieved form http://www.jstor.org/discover/10.2307/20033001?uid=2\&uid=4\&sid=21103738854003

Firth, C. (2014). The Smallest Things Can Make the Largest Difference to Assylm Seekers Facing Destitution. Refugee Council. Retrieved from http://www.refugeecouncil.org.uk/how_you_can_help_us/appeals/2473_appeal_from_colin_firth?gclid=CK Siop-w6MACFdMbtAoddzQAIg

Harrell-Bond, B. (2000). Are Refugee Camps Good for Children? Working Paper No. 29. Retrieved from http://www.unhcr.org/3ae6a0c64.pdf

IRIN News. (2012). SYRIA: Ten things to watch out for. Retrieved from http://www.irinnews.org/Report/96286/SYRIA-Ten-things-to-watch-out-for last

IRIN. (2012). Syria: Healthcare System Crumbling. Retrieved from http://www.irinnews.org/report/97011/syria-healthcare-system-crumbling

Jabbour, G. (2006). Syrian women and human rights. Damascus University, pp. 2. Retrieved from http://www.fafo.no/ais/middeast/syria/syrianwomen/SW-Jabbour.pdf

Letsch, C. (2014). Syrian Refugees Trigger Labor Boom in Turkey. The Guardian. Retrieved from http://www.theguardian.com/law/2014/sep/02/syria-refugees-child-labour-turkey

Manfreda, P. (2013), Syrian Civil War Explained, Middle East news. Retrieved from http://middleeast.about.com/od/syria/tp/Syrian-Civil-War-Explained.htm

McClelland, M. (2014). How to Build a Perfect Refugee Camp. The New York Times. Retrieved from http://www.nytimes.com/2014/02/16/magazine/how-to-build-a- $\quad$ perfect-refugee-camp.html?_r=0

McMahon, R. (2013). The Dilemma of Humanitarian Intervention. Counsel on Foreign Relations. Retrieved from http://www.cfr.org/humanitarian- intervention/dilemma-humanitarian-intervention/p16524

Munhall, P. (1988). Ethical considerations in qualitative research. Western Journal of Nursing Research, 10(2), 150-162. http://dx.doi.org/10.1177/019394598801000204

NATO. (2014). Current crisis in Syria, Background Report, p. 2-10. Retrieved from http://www.studentsummit.cz/data/1354903402701NATO_Current-crisis-in-Syria.pdf

Neuman, L. (2005). Social research methods: qualitative and quantitative approaches (6th ed.). Boston, PA: Allyn and Bacon. 
Neuman, L. W. (2007). Social Research Methods, 6/E. Pearson Education India. Retrieved from $\mathrm{http} / /$ books.google.com.uk/books?hl=en\&lr=\&id=8eftmoqgM10C\&oi=fnd\&pg=PR7\&dq=Neuman\&ots=B 6rNbYNX6c\&sig=I_FJLFLRCa6YUhwsAEfruBxzQ9A\&redir_esc $=\mathrm{y} \# \mathrm{v}=$ onepage $\& \mathrm{q}=$ Neuman $\& \mathrm{f}=$ false

Observation from Save the Children's work; see also USAID. (2012). Syria - Complex Emergency, Fact Sheet \#4, 21 November, p 4, United States Agency for International Development. Retrieved from http://transition.usaid.gov/our_work/humanitarian_assistance/disaster_assistance/countries/syria/template/fs _sr/fy2013/syria_ce_fs04_11-21-2012.pdf

Ogata, S. (n.d.). Refugee Children: Guidelines on Protection and Care. Retrieved from http://www.unicef.org/violencestudy/pdf/refugee_children_guidelines_on_protection_and care.pdf

OHCHR. (2013). Report of the independent international commission of inquiry on the Syrian Arab Republic. Pp. $21-22$, Retrieved from http://www.ohchr.org/EN/HRBodies/HRC/IICISyria/Pages/IndependentInternationalCommission

Onwuegbuzie, A. J., \& Jiao, Q. G. (2006). Prevalence of mixed methods sampling designs in social science research and beyond. Paper presented at the meeting of the American Educational Research Association, San Francisco.

Pillay, N. (2014). No Longer a Quarrel in a Faraway Country, The Syria Conflict Affects Us All. The Guardian, Retrieved from http://www.theguardian.com/global/commentisfree/2014/aug/22/syria-conflict-murderous-summer-united-n ations

Raha, M. (2013). Syria: A modern humanitarian failure, Middle East Monitor. Retrieved from

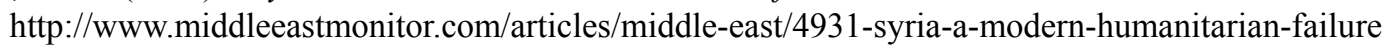

ReliefWeb. (2013). Un Agencies And NGOs Call For Appropriate Feeding Of Infants And Young Children In The Syria Emergency. Retrieved from: http://reliefweb.int/reports/syrian-arab-republic/un-agencies-and-ngos-call-appropriate-feeding-infants-andyoung-children

Rieff, D. (2003). A Bed for the Night: Humanitarianism in Crisis. Simon \& Schuster.

Saunders, M. N., Saunders, M., Lewis, P., \& Thornhill, A. (2011). Research methods for business students, 5/e. Pearson Education India.

Save the Children. (2013). Protecting Children in Emergencies. Retrieved from http://rwanda.savethechildren.net/sites/rwanda.savethechildren.net/files/library/Save $\% 20$ the $\% 20$ Children $\%$ 20 in\%20emergencies\%5B1\%5D.pdf

Simon I. (2014). Under Siege: The devastating impact on children of three years of conflict in Syria. UNICEF, pp. 4-10. Retrieved from http://www.unicefusa.org/assets/pdf/UN01137.pdf

Stevis, M. (2014). Human-Rights Groups Lash Out at EU Treatment of Syrian Refugees. Wall Street Journal. Retrieved

from http://blogs.wsj.com/brussels/2014/01/22/human-rights-groups-lash-out-at-eu-treatment-of-syrian-refugees/

Syria: One Year On, No Justice for Chemical Attacks Victims. (2014). Retrieved from http://www.hrw.org/news/2014/08/21/syria-one-year-no-justice-chemical-attacks-victims

Syrian Network for Human Rights, cited in Syria Needs Analysis Project (SNAP). (2013). Regional Analysis for Syria, Assessment Capacities Project (ACAPS). Retrieved from http://www.acaps.org/disaster-needs-analysis

Tashakkori, A., \& Teddlie, C. (2003). The past and future of mixed methods research: From data triangulation to mixed model designs. In A. Tashakkori, \& C. Teddlie (Eds.), Handbook of mixed methods in social\& behavioral research (pp. 671-702). Thousand Oaks, CA: Sage.

Tesch, R. (2013). Qualitative research: Analysis types and software. Routledge.

The Future of Syria: Refugee Children in Crisis. (2014). UNHCR. Retrieved from http://www.rcusa.org/uploads/pdfs/Future-of-Syria-UNHCR-v13.pdf

Trenin, D. (2013). The Mythical Alliance: Russia's Syria Policy. Carnegie Moscow Center. Retrieved from http://carnegieendowment.org/files/Brief-Trenin-RussiaSyriall.pdf

UN \& USA Quietly Dumping Thousands of Potential Syrian Terrorist Refugees into United States RIGHT NOW. 
(2014).

Retrieved

from

http://beforeitsnews.com/alternative/2014/09/breaking-un-usa-quietly-dumping-thousands-of-potential-syria n-terrorist-refugees-into-united-states-right-now-3030170.html

UN News Service. (2013). UN officials alarmed by effect of systematic violence on civilians in Syria. Retrieved from http://reliefweb.int/report/syrian-arab-republic/un-official-alarmed-effect-systematic-violence-civilians -syria

UNHCR report puts spotlight on the exploitation and misery of Syria's children. (2013). Retrieved from http://www.unhcr.org/5295b1cf6.html

UNHCR. (2007). Through the eyes of a child: refugee children speak about violence. Retrieved from http://www.unhcr.org/47c804682.pdf

UNHCR. (2013). UNHCR Global Appeal Update 2013 Update. P. 168. Retrieved from: http://www.unhcr.org/50a9f829a.html

UNICEF. (2009). State of the World's Children: Celebrating 20 Years of the Convention on the Rights of the Child. Unicef.

UNICEF. (2013). A Lost Generation: A strategy for children affected by the Syrian Crisis. Retrieved from http://www.unicef.org/appeals/files/Lost_Generation___Final_Draft_for_distribution_to_participants_09Oct 2013.pdf

UNICEF. (2014). At a Glance: Syrian Arab Republic. Retrieved from http://www.unicef.org/infobycountry/syria_statistics.html

UNICEF. (2014). Emergency Alert: Children of Syria'. p. 3. Retrieved from: http://www.unicef.org.uk/Documents/Publications/UNICEFEmergencyAlert_Syria_Jan14.pdf

UNICEF. (2014). Number of children affected by Syrian war doubled in last year. Retrieved from http://www.dw.de/number-of-children-affected-by-syrian-war-doubled-in-last-year-says-unicef/a-17486675

UNICEF. (2014). Syrian Children under Siege. Retrieved from http://www.unicefusa.org/mission/emergencies/conflict/syria

War Child Holland. (2013). Psychological support in emergencies: Critical support for Syrian children. pp. 12-13. Retrieved from http://www.warchildholland.org/sites/default/files/bijlagen/node_14/10-2013/psychosocial_support_in_eme rgencies_-_critical_for_syrian_children_-_war_child_holland_2013.pdf

Williams, R. (2012). Syria: A war on childhood. pp. 4-8. Retrieved from http://www.warchild.org.uk/sites/default/files/Syria\%20-\%20War\%20on\%20Children(final).pdf

World Health Organization. (2013). Syrian Arab Republic, Jordan, Lebanon, Iraq Monthly Situation Report, (18). Retrieved http://www.emro.who.int/images/stories/syria/documents/Syria_crisis_SitRep_WHO_18_01_Oct.pdf

\section{Copyrights}

Copyright for this article is retained by the author(s), with first publication rights granted to the journal.

This is an open-access article distributed under the terms and conditions of the Creative Commons Attribution license (http://creativecommons.org/licenses/by/3.0/). 